\title{
"Is The Banking Industry The Right Choice To Invest?" (Analisis Laporan Keuangan PT. Bank Central Asia, PT. Bank Rakyat Indonesia, PT. Bank Nasional Indonesia, PT. May Bank dan PT. Bank Permata Periode 2013-2017)
}

\author{
Silmi $^{1}$, Kevry Ramdany ${ }^{2}$, Yudi Mufti Prawira ${ }^{3}$ \\ ${ }^{1,3}$ Fakultas Ekonomi Pasca Sarjana Akuntansi Universitas Andalas Padang, Indonesia \\ ${ }^{2}$ Sekolah Tinggi Ilmu Ekonomi Haji Agus Salim Bukittinggi, Indonesia \\ Corespondence Email: c.silmi1612@gmail.com
}

\begin{abstract}
Abstrak. Laporan keuangan merupakan salah satu alat analisis yang berisi informasi yang dapat digunakan oleh calon investor untuk membuat keputusan dalam berinvestasi. Calon investor membutuhkan seorang analis yang mampu dan handal untuk menganalisis laporan keuangan industri pada Bank, untuk menentukan Bank manakah yang terbaik bagi calon investor jangka pendek dan calon investor jangka panjang didalam menanamkan modalnya melalui pembelian saham, tentunya pada Bank yang kinerja keuangannya terbaik dan dapat mengembalikan tingkat return investasi sesuai yang diharapkan oleh para calon investor bahkan lebih. Ada 5 Bank yang penulis bandingkan dan rangkingkan nilai rasio dan kinerjanya pada penelitian ini sehingga calon investor dapat berinvestasi dengan tepat, diantaranya: PT. Bank Central Asia, PT. Bank Rakyat Indonesia, PT.Bank Nasional Indonesia, PT. May Bank dan PT. Bank Permata, selama 5 tahun waktu periode analisis. Dari hasil penelitian dan analisa yang penulis lakukan, Bank BCA adalah pilihan yang tepat dalam berinvestasi bagi calon investor jangka pendek dan Bank BRI adalah pilihan yang tepat bagi calon investor jangka panjang dalam berinvestasi.
\end{abstract}

Kata Kunci: Rasio Keuangan; Bank; Investor Jangka Panjang; Investor Jangka Pendek

\begin{abstract}
Financial statements are one of the analytical tools that contain information that can be used by potential investors to make investment decisions. Prospective investors need a capable and trusted analysis to analyze the financial statements of the industry in the Bank, to determine which banks need funds for short-term investors and long-term prospective investors involve investing their capital through the purchase of shares, explained to the Bank that provides funds as expected investment returns by potential investors even more. There are 5 banks that submit comparisons and assess their ratios and performance in this study so that potential investors can invest appropriately, expecting: PT. Bank Central Asia, PT. Bank Rakyat Indonesia, PT. Bank Nasional Indonesia, PT. May Bank and PT. Bank Permata, for 5 years analysis time period. From the results of research and analysis conducted, Bank BCA is the right choice for investors for short-term investors and BRI is the right choice for potential investors for long-term investment.
\end{abstract}

Keywords: Financial Ratios; Banks; Long-Term Investors; Short-Term Investors

\section{PENDAHULUAN}

Perkembangan dunia pasar investasi semakin mengalami peningkatan begitupun minat dan permintaan dari seluruh kalangan masyarakat. Banyak dari masyarakat yang berminat menginvestasikan kekayaannya untuk membeli saham disuatu perusahaan atau industri. Namun, tidak sedikit dari calon investor tersebut menemukan kesulitan dan dilema disaat memilih industri apa yang terbaik untuk menginvestasikan kekayaannya. Disinilah bantuan dari seorang analis laporan keuangan dibutuhkan untuk menilai kinerja dari calon-calon industri yang akan dijadikan tempat untuk berinvestasi bagi klien mereka melalui penganalisaan rasio keuangan dari industri yang bersangkutan (Handayani, 2011).

Bank merupakan salah satu industri ekonomi untuk berinvestasi, Bank memperjual belikan sahamnya ke publik pada pasar modal (Jiwandono, 2014). Menurut isi dari Pernyataan Standar Akuntansi Keuangan (PSAK) No. 31" Bank adalah suatu lembaga yang berperan sebagai perantara keuangan antara pihak-pihak yang memerlukan dana serta sebagai lembaga yang berfungsi memperlancar lalu lintas pembayaran" (finansialku). Didalam menganalisa laporan keuangan Bank yang akan ditawarkan kepada klien, analis harus mengetahui terlebih dahulu motif dari kliennya, apakah klien ini termasuk investor jangka pendek atau merupakan investor jangka panjang, karena akan berbeda alat analisis yang dipakai untuk investor jangka pendek dan alat analisis yang dipakai untuk investor jangka panjang. Investor jangka pendek cendrung hanya mementingkan pengembalian investasi dalam kurun waktu maksimal 1 tahun dan bisa diambil sewaktu-waktu jika membutuhkannya dan untuk investor jangka panjang bisa menikmati hasil investasi dengan waktu lebih dari 5 tahun.

Menurut Sutarti, (2011) "suatu rasio tidak memiliki arti dalam dirinya sendiri, melainkan harus diperbandingkan dengan rasio yang lain agar rasio tersebut menjadi lebih sempurna dan untuk melakukan 
analisis ini dapat dengan cara membandingkan prestasi suatu periode dengan periode sebelumnya sehingga diketahui adanya kecenderungan selama periode tertentu, selain itu dapat pula dilakukan dengan membandingkan dengan perusahaan sejenis dalam industri itu sehingga dapat diketahui bagaimana keuangan dalam masing-masing industri” .

Permasalahan dari paper ini yaitu dengan semakin meningkatnya keinginan dan permintaan investor didalam berinvestasi pada dunia pasar modal, maka dibutuhkanlah seorang analis yang mampu dan handal untuk menganalisis laporan keuangan industri pada Bank, untuk menentukan manakah Bank yang terbaik bagi investor jangka pendek dan investor jangka panjang didalam menanamkan modalnya melalui pembelian saham, tentunya pada Bank yang kinerja keuangannya terbaik dan dapat mengembalikan tingkat return investasi sesuai yang diharapkan oleh para calon investor bahkan lebih. Ada 5 Bank yang akan penulis bandingkan dan rangkingkan nilai rasio dan kinerjanya pada paper ini sehingga investor dapat berinvestasi dengan tepat, diantaranya: PT. Bank Central Asia, PT. Bank Rakyat Indonesia, PT.Bank Nasional Indonesia, PT. May Bank dan PT. Bank Permata, selama 5 tahun waktu periode analisis.

Karena Bank merupakan salah satu sektor industri yang memberikan kontribusi untuk memajukan ekonomi melalui pasar modal yang melayani investasi bagi para calon investornya, oleh karena itu akan sangat penting untuk dipelajari dan dianalisis bagaimana ukuran kriteria nilai rasio yang terbaik untuk dapat menghasilkan return investasi dan merupakan suatu tugas penting bagi analis dari hasil analisis nilai rasionya tersebut untuk dapat memberikan rekomendasi kepada calon-calon investor didalam berinvestasi pada bank yang memiliki kriteria return dan kinerja yang baik dan tentunya sesuai dengan yang diharapkan oleh calon investor.

\section{METODE}

\section{Populasi dan Sampel}

Populasi dari penelitian ini yaitu Perbankan yang terdaftar di Indonesian Stock Exchange (idx) untuk laporan keuangan periode 2013-2017.

Sampel dari penelitian ini yaitu, PT Bank Central Asia Tbk, PT Bank Rakyat Indonesia Tbk, PT Bank Negara Indonesia Tbk, PT Bank Maybank Tbk dan PT Bank Permata, Tbk.

\section{Metode Pengumpulan dan Jenis Data}

Metode pengumpulan data dari perusahaan perbankan yang terdaftar di Bursa Efek Indonesia (BEI) laporan keuangan periode 2013 sampai periode 2017.

Jenis dari penelitian termasuk kedalam penelitian sekunder. Dan metode penlitiaannya penelitian kuantitatif.

\section{Model Penelitian}

Model penelitian ini menggunakan alat analisis rasio keuangan investasi.

Jenis-jenis rasio yang digunakan dalam menilai kinerja sektor perbankan bagi investor jangka panjang dan investor jangka pendek diantaranya:

\section{Analisis Ratio}

Debt Ratio Rasio ini menunjukkan kemampuan perusahaan membiayai asset dengan pinjaman atau kewajibannya (Listyorini, 2012). Berarti seberapa besar dana yang dipinjam perusahaan dari pihak luar untuk membiayai aset. Sehingga ketika rasio ini mengindikasikan semakin besar aset yang dibiayai oleh hutang, semakin sedikit aset yang bisa dibiayai melalui modal, sehingga total beban bunga hutang pun akan meningkat dan mengindikasikan semakin tinggi resiko perusahaan membayar hutangnya. Maka yang menjadi angka terbaik itu adalah rasio terendah. Industri perbankan adalah perusahaan yang mengelola dana pihak ketiga dan sebagian besar liabilitas adalah dana dari pihak ketiga yang dikelola jadi semakin tinggi hutang perusahaan bank bukan berarti perusahaan bank akan semakin dinilai buruk karena semakin besar modal pihak ketiga yang mereka kelola, maka kemungkinan untuk mendapat laba usaha juga semakin tinggi. Debt Ratio penting didalam proses pengambilan keputusan untuk rekomendasi bagi investor jangka panjang maupun jangka pendek.

\section{Economic Value Edit}

EVA merupakan suatu konsep penilaian kinerja keuangan perusahaan yang dikembangkan oleh Stem Stewart \& Co. Economic Value Added (EVA) atau disebut juga dengan nilai tambah ekonomis (NITAMI) diartikan sebagai suatu konsep yang dilandasi oleh pemikiran bahwa dalam pengukuran laba operasi perusahaan harus dengan adil mempertimbangkan harapan-harapan setiap penyedia dana (kreditur dan pemegang saham). Derajat keadilannya dinyatakan dengan ukuran tertimbang dan struktur modal yang ada. NITAMI (EVA) merupakan rasio yang penting didalam proses pengambilan keputusan untuk rekomendasi bagi investor jangka panjang.

\section{Financial Distress}

Kesulitan keuangan atau financial distress adalah keadaan dimana perusahaan menemui kesulitan atau bahkan tidak bisa untuk membayar kewajiban keuangannya kepada para kreditur (Rahmawati \& Hadiprajitno, 2015). Meskipun financial distress kesulitan membayar kewajiban kepada kreditur, akan tetapi rasio ini juga harus dipertimbangkan oleh calon investor, karna perusahaan yang mengalami kesulitan keuangan ditakutkan tidak bisa membayarkan return investasi dari para investor. Rasio ini menjadi 
pertimbangan bagi investor jangka panjang dan investor jangka pendek.

\section{Analisis Dupont}

Rasio Equity Multiplier menunjukkan kemampuan perusahaan dalam mendayagunakan ekuitas pemegang saham (Afrianti, 2012). Rasio ini juga bisa diartikan sebagai beberapa porsi dari aktiva perusahaan yang dibiayai oleh pemegang saham. Semakin kecil rasio ini berarti porsi pemegang saham akan semakin besar, sehingga kinerjanya semakin baik karena persentase untuk pembayaran bunga semakin kecil (Ariyanti, 2010).

\section{Analisis Leverage}

Financial leverage berhubungan dengan hutang bank baik dari sekuritas hutang maupun dengan sekuritas ekuitas bank yang dimana sekuritas hutang membayar bunga obligasi dan sekuritas ekuitas membayar deviden, jadi pendapatan perusahaan harus lebih besar dari pada yang dikeluarkan untuk beban atau biaya leverage seperti deviden atau bunga obligasi jika beban leverage lebih besar berarti perusahaan mengalami kerugian (Sofyaningsih \& Hardiningsih, 2011). Perubahan pendapatan (Revenue) dapat mempengaruhi laba bersih (Net income/EBIT) sementara laba bersih akan mempengaruhi laba perlembar saham (EPS) (Subramanyam, 2017).

- Degree Of Operating Leverage

- Degree Of Financial Leverage

- Degree Of Capital Leverage

\section{CAMEL}

CAR (Capital) adalah "rasio kecukupan modal yang berfungsi menampung risiko kerugian yang kemungkinan dihadapi oleh bank (Fitrianto \& Mawardi, 2006). Semakin tinggi CAR maka semakin baik kemampuan bank tersebut untuk menanggung risiko dari setiap kredit/aktiva profit yang berisiko". Jika nilai CAR tinggi maka bank tersebut mampu membiayai kegiatan operasional dan memberikan kontribusi yang cukup besar bagi profitabilitas.
Asset, Perhitungan kualitas aktiva produktif (KAP) menggunakan 2 rasio, yaitu rasio aktiva produktif yang diklasifikasikan terhadap jumlah aktiva produktif (Aini, 2013). Aktiva suatu bank akan dinilai berdasarkan kualitas aktifa produktif (KAP) yang diklasifikasikan adalah aktiva produktif, baik yang sudah maupun yang mengandung potensi tidak memberikan penghasilan atau menimbulkan kerugian. Kualitas Aktiva Produktif (KAP) adalah rasio yang digunakan untuk menghitung perbandingan antara aktiva produktif yang diklasifikasikan (APYD) berdasarkan ketentuan yang berlaku terhadap total Aktiva Produktif (AP) (Ariyanti, 2010). PPAP (Penyisihan Penghapusan Ativa Produktif) digunakan untuk menghitung perbandingan antara penyisihan penghapusan aktiva produktif yang dibentuk (PPAPYD) terhadap penyisihan Penghapusan Aktiva Produktif yang wajib Dibentuk (PPAPWD) (Sujarweni, 2015).

Manajemen adalah proses merencanakan, mengarahkan dan menyelesaikan suatu pekerjaan dengan kerjasama atau bantuan orang lain yang kompak untuk mencapai tujuan bersama secara efektif dan efesien. Manajemen atau pengelolaan suatu bank akan menentukan sehat tidaknya suatu bank (Sujarweni, 2015).

Earning (Rentabilitas) atau earning power merupakan salah satu unsur yang dinilai untuk menentukan sehat tidaknya bank (Sapariyah, 2010). Rentabilitas adalah kemampuan bank untuk menghasilkan laba atau keuntungan mennggunakan aktiva atau modal yang dimilikinya selama periode tertentu (Sujarweni, 2015).

- Rentabilitas: ROA, BOPO

Likuiditas, suatu bank dikatakan likuid apabila bank bersangkutan dapat memenuhi kewajiban hutanghutangnya, dapat membayar kembali semua depositonya, serta dapat memenuhi permintaan kredit yang diajukan tanpa terjadi penangguhan.

- Penilaian Likuiditas.

- Loan to Deposit Ratio (LDR).

\section{HASIL DAN PEMBAHASAN}

Tabel 1. Table Rank Analisis Debt Ratio

\begin{tabular}{lccccccc}
\hline & $\mathbf{2 0 1 3}$ & $\mathbf{2 0 1 4}$ & $\mathbf{2 0 1 5}$ & $\mathbf{2 0 1 6}$ & $\mathbf{2 0 1 7}$ & Rata-Rata & Ranking Terbaik \\
\hline BBCA & 0,87 & 0,86 & 0,84 & 0,83 & 0,82 & 0,84 & $\mathbf{1}$ \\
BBRI & 0,87 & 0,88 & 0,87 & 0,85 & 0,85 & 0,86 & $\mathbf{2}$ \\
BBNI & 0,88 & 0,85 & 0,85 & 0,85 & 0,86 & 0,86 & $\mathbf{3}$ \\
MAYA & 0,91 & 0,89 & 0,90 & 0,88 & 0,88 & 0,89 & $\mathbf{4}$ \\
BNLI & 0,91 & 0,91 & 0,90 & 0,88 & 0,85 & 0,89 & $\mathbf{5}$ \\
\hline
\end{tabular}

Yang menjadi angka terbaik $t$ dilihat persentase yang tertinggi ada pada perusahaan BNLI dan MAYA, tetap dari perbandingan hutang dan asset ke lima bank masih menunjukkan nilai di bawah 1 Rata-rata industri menunjukan elemen asset masih lebih tinggi dibandingkan liabilitasnya, jadi liabilitas masih mampu ditutupi lewat asset yang dimiliki, dan dari rata-rata industri menunjukkan asset perusahaan di biayai lebih dari $80 \%$ assetnya dibiayai oleh liabilitas, hal ini wajar karena industri perbankan adalah perusahaan yang mengelola dana pihak ketiga dan sebagian besar libilitas adalah dana dari pihak ketiga yang dikelola jadi semakin 
Silmi et al, "Is The Banking Industry The Right Choice To Invest?"(Analisis Laporan Keuangan PT. Bank Central Asia, PT. Bank Rakyat Indonesia, PT. Bank Nasional Indonesia, PT. May Bank dan PT. Bank Permata Periode 2013-2017)

tinggi hutang perusahaan bank bukan berarti perusahaan bank akan semakin dinilai buruk karena semakin besar modal pihak ketiga yang mereka kelola, maka kemungkinan untuk mendapat laba usaha juga semakin tinggi.

Tabel 2. Table Rank Analisis EVA (NITAMI)

\begin{tabular}{|c|c|c|c|c|c|c|c|}
\hline BANK & 2013 & 2014 & 2015 & 2016 & 2017 & $\begin{array}{c}\text { Rata-rata } \\
\text { Perusahaan }\end{array}$ & Rank Terbaik \\
\hline BCA & Rp 12.657.885 & Rp.12.219.241 & Rp 16.195.094 & Rp.19.306.147 & Rp.17.656.184 & Rp. 15.606.910 & 2 \\
\hline $\mathrm{BNI}$ & Rp. 5.559.853 & Rp. 6.916.665 & Rp. 9.549.312 & Rp.10.114.226 & Rp.11.550.432 & Rp. 8.738.114 & 3 \\
\hline BRI & Rp. 12.834 .556 & Rp.17.302.236 & Rp. 9.891 .480 & Rp.25.171.148 & Rp.26.101.005 & Rp. 18.260.085 & 1 \\
\hline MAYA & Rp. 1.484 .375 & Rp. 672.466 & Rp. 1.108 .153 & Rp. 1.824 .131 & Rp. 1.855 .185 & Rp. 1.388 .862 & 4 \\
\hline BNLI & Rp. (8.435.759) & Rp. (15.285.800) & Rp. (3.554.509) & Rp. (41.097.825) & $\operatorname{Rp}(12.094 .218)$ & Rp. (16.093.622) & 5 \\
\hline Rata-rata Industri & Rp. 4.820 .182 & Rp. 4.364.961 & Rp. 6.637.906 & Rp. 3.063.565 & Rp. 9.013.717 & & \\
\hline
\end{tabular}

Dari tabel diatas dapat dilihat bahwa rata-rata EVA (NITAMI) tertinggi ada pada Bank BRI, ini berarti antara ke-5 Bank ini, Bank BRI merupakan Bank yang paling tinggi terjadinya nilai tambah ekonomis (NITAMI), sehingga semakin besar EVA yang dihasilkan maka harapan para penyandang dana dapat terpenuhi dengan baik, yaitu mendapatkan pengembalian investasi yang sama atau lebih dari yang diinvestasikan dan kreditur mendapatkan bunga. Keadaan ini menunjukkan bahwa perusahaan berhasil menciptakan nilai (create value) bagi pemilik modal sehingga menandakan bahwa kinerja keuangannya baik. Rasio ini dapat dijadikan pertimbangan investasi bagi investor jangka panjang.

Tabel 3. Table Rank Analisis Financial Distress

\begin{tabular}{lccccccc}
\hline \multicolumn{1}{c}{ BANK } & $\mathbf{2 0 1 3}$ & $\mathbf{2 0 1 4}$ & $\mathbf{2 0 1 5}$ & $\mathbf{2 0 1 6}$ & $\mathbf{2 0 1 7}$ & Rata-Rata & Rank Terbaik \\
\hline PT. Bank BCA & $(12.27)$ & $(12.87)$ & $(13.14)$ & $(13.29)$ & $(13.61)$ & $(13.04)$ & $(1.6)$ \\
PT. Bank BNI & $(1.24)$ & $(2.52)$ & $(1.61)$ & $(1.59)$ & $(1.44)$ & $(11.68)$ & $\mathbf{2}$ \\
PT. Bank BRI & $(14.66)$ & $(12.90)$ & $(12.35)$ & $(11.19)$ & $(11.05)$ & $(9.50)$ & $(3.18)$ \\
PT. May Bank & $(3.41)$ & $(1.41)$ & $(2.43)$ & $(4.57)$ & $(4.11)$ & $(7.35)$ & $\mathbf{3}$ \\
PT. Bank Permata & $(9.56)$ & $(9.51)$ & $(9.42)$ & 0.91 & $(9.20)$ & $\mathbf{4}$ \\
RATA-RATA & $(8.23)$ & $(7.84)$ & $(7.79)$ & $(5.95)$ & $(7.88)$ & & \\
\hline
\end{tabular}

Dari tabel diatas dapat dilihat bahwasanya Bank dengan nilai rasio financial distress diatas angka 0 berindikasi sedang kesulitan keuangan atau mengalami financial distress, dimana bank yang bersangkutan menemui kesulitan atau bahkan tidak mampu untuk membayar kewajiban keuangannya kepada para kreditur yang nantinya akan berujung kepada kebangkrutan Bank yang bersangkutan. Financial distress ini satu-satunya terjadi pada Bank Permata ditahun 2016, dimana rasio financial distressnya besar dari angka 0 , yaitu senilai 0,91. Diketahui dari Comprehensive Income Statement Bank Permata memang pada tahun 2016 Bank Permata mengalami kerugian bersih. Rasio ini digunakan oleh investor jangka panjang untuk menilai kelayakan bank sebagai tempat mereka berinvestasi.

Tabel 4. Table Rank Analisis Rasio Equity Multiplier

\begin{tabular}{lccccccc}
\hline & 2013 & 2014 & 2015 & 2016 & 2017 & Rata-Rata & Rank Terbaik \\
\hline BBCA & 7,790 & 7,090 & 6,630 & 6,000 & 5,710 & $\mathbf{6 , 6 4 4}$ & $\mathbf{1}$ \\
BBRI & 7,890 & 8,200 & 7,760 & 6,830 & 6,720 & $\mathbf{7 , 4 8 0}$ & $\mathbf{3}$ \\
BBNI & 8,110 & 6,830 & 6,480 & 6,760 & 7,030 & $\mathbf{7 , 0 4 2}$ \\
Permata & 11,740 & 10,840 & 9,710 & 8,580 & 6,900 & $\mathbf{9 , 5 5 4}$ & $\mathbf{2}$ \\
MAYA & 11,320 & 9,780 & 10,010 & 8,600 & 0,100 & $\mathbf{7 , 9 6 2}$ & $\mathbf{4}$ \\
Rata-rata & 9,370 & 8,548 & 8,118 & 7,354 & 5,292 & $\mathbf{7 , 7 3 6}$ & \\
\hline
\end{tabular}

Semakin besar nilai rasio keuangan ini maka menunjukkan semakin banyak porsi hutang digunakan untuk membiayai bisnis tersebut. Maka pada grafik dapat dilihat bahwa nilai rata-rata industri perbankan pada tahun 2013-2017 nilai rasio eqm terbesarnya yaitu
Permata Bank menunjukkan bahwa bank ini tidak memiliki hutang yang banyak dalam membiayai bisnisnya sedangkan yang memiliki porsi hutang paling sedikit adalah Bank BCA sehingga baik untuk investor jangka panjang.

Tabel 5. Table Rank Analisis Degree of Operating Leverage (DOL)

\begin{tabular}{|c|c|c|c|c|c|c|c|}
\hline & 2013 & 2014 & 2015 & 2016 & 2017 & Rata-Rata & Rata-Rata Terbaik \\
\hline BBCA & 0,98 & 0,70 & 0,59 & 1,17 & 2,19 & 1,12 & 2 \\
\hline BBRI & 1,01 & 0,68 & 0,32 & 0,23 & 1,04 & 0,65 & 3 \\
\hline BBNI & 2,27 & 1,48 & 0,89 & 2,01 & 1,29 & 1,59 & 1 \\
\hline BNLI & 1,95 & $-0,20$ & $-0,52$ & $-2,87$ & $-1,95$ & $-0,72$ & 5 \\
\hline MAYA & 0,77 & 0,97 & 1,01 & 1,03 & 1,11 & 0,98 & 4 \\
\hline RATA-RATA & 1,39 & 0,72 & 0,46 & 0,31 & 0,74 & & \\
\hline
\end{tabular}


Untuk analisis perperusahaan angka terbaik di pegang oleh bank BBNI yang nilainya terus meningkat hal ini berarti setiap tahunnya persentase pendapatan bank BBCA terus meningkat pesat mempengaruhi ebitnya yang berarti jika tahun 2018 diprediksi pendapatan tahun depan meningkat $10 \%$ maka akan meningkatkan laba bersih sebanyak 21,9\% ditahun depan. Untuk bank Permata berada di kondisi terpuruk yang dimana menghasilkan nilai negatif dengan rata-rata selama lima tahun $-0,72$ yang artinya beban leverage lebih besar berarti perusahaan mengalami kerugian dan diprediksi tahun depan masih belum mampu untuk menghasilkan pendapatan untuk menambah nilai EBIT.

Hasil Analisis Dengan CAMEL

Tabel 6. Table Rank Analisis Capital

\begin{tabular}{ccccccccc}
\hline CAR & BBRI & MAYA & BBCA & BNLI & BBNI & AVERAGE & Rank Terbaik \\
\hline $\mathbf{2 0 1 3}$ & $18,50 \%$ & $11,00 \%$ & $12,90 \%$ & $9,79 \%$ & $15,1 \%$ & $13,46 \%$ & BCA \\
$\mathbf{2 0 1 4}$ & $17,34 \%$ & $13,00 \%$ & $19,86 \%$ & $9,72 \%$ & $16,2 \%$ & $15,22 \%$ & BRI \\
$\mathbf{2 0 1 5}$ & $17,49 \%$ & $13,00 \%$ & $20,29 \%$ & $10,94 \%$ & $19,5 \%$ & $16,24 \%$ & BNI \\
$\mathbf{2 0 1 6}$ & $20,58 \%$ & $13,00 \%$ & $24,01 \%$ & $12,76 \%$ & $19,5 \%$ & $17,97 \%$ & MAYA \\
$\mathbf{2 0 1 7}$ & $21,49 \%$ & $16,00 \%$ & $25,27 \%$ & $15,43 \%$ & $18,5 \%$ & $19,34 \%$ & PERMATA \\
AVERAGE & $\mathbf{1 9 , 0 8 \%}$ & $\mathbf{1 3 , 2 0 \%}$ & $\mathbf{2 0 , 4 6 \%}$ & $\mathbf{1 1 , 7 3 \%}$ & $\mathbf{1 7 , 7 6 \%}$ & & \\
\hline
\end{tabular}

Nilai minimal bank dikatakan sehat adalah $>=8 \%$ dari keseluruhan nilai berada diatas $8 \%$ dan terus meningkat setiap tahun dari nilai rata-rata $13,46 \%$ di tahun 2013 ke 19,34\% di tahun 2017. Dalam tabel dan grafik dapat dilihat bahwa BBCA memiliki rata-rata tertinggi dari bank lainnya, yaitu dengan nilai rata-rata $20,46 \%$. Kemudian di ikuti oleh BBRI dengan nilai ratarata $19,08 \%$. Dan nilai terendah ada pada BNLI (Permata) dengan rata-rata 11,73\%.

Tabel 7. Analisis Kualitas Aktiva Produktif (KAP) dan Penyisihan Aktiva Produktif (PPAP)

\begin{tabular}{|c|c|c|c|c|c|c|}
\hline KAP & BRI & MAYA & BBCA & BNLI & BBNI & AVERAGE \\
\hline 2013 & $1,16 \%$ & $0,03 \%$ & $0,38 \%$ & $0,27 \%$ & $1,9 \%$ & $0,75 \%$ \\
\hline 2014 & $1,28 \%$ & $0,01 \%$ & $0,53 \%$ & $43,48 \%$ & $1,8 \%$ & $9,42 \%$ \\
\hline 2015 & $1,04 \%$ & $0,79 \%$ & $0,64 \%$ & $8,00 \%$ & $2,1 \%$ & $2,51 \%$ \\
\hline 2016 & $0,96 \%$ & $0,32 \%$ & $1,25 \%$ & $27,22 \%$ & $2,7 \%$ & $6,49 \%$ \\
\hline 2017 & $1,00 \%$ & $0,01 \%$ & $1,27 \%$ & $7,10 \%$ & $2,0 \%$ & $2,28 \%$ \\
\hline AVERAGE & $1,09 \%$ & $3,23 \%$ & $\mathbf{0 , 8 1 \%}$ & $17,21 \%$ & $2,10 \%$ & \\
\hline PPAP & BRI & MAYA & BBCA & BNLI & BBNI & AVERAGE \\
\hline 2013 & $210 \%$ & $54,00 \%$ & $362 \%$ & $106,33 \%$ & $105 \%$ & $167 \%$ \\
\hline 2014 & $193,82 \%$ & $63,00 \%$ & $391 \%$ & $4,42 \%$ & $91,2 \%$ & $149 \%$ \\
\hline 2015 & $199,03 \%$ & $49,00 \%$ & $471 \%$ & $3,63 \%$ & $65,2 \%$ & $158 \%$ \\
\hline 2016 & $240 \%$ & $11,00 \%$ & $604 \%$ & $4,40 \%$ & $73,3 \%$ & $187 \%$ \\
\hline 2017 & $281,40 \%$ & $43,00 \%$ & $571 \%$ & $7,01 \%$ & $76,2 \%$ & $196 \%$ \\
\hline AVERAGE & $224,85 \%$ & $44,00 \%$ & $479,75 \%$ & $25,16 \%$ & $82,18 \%$ & \\
\hline
\end{tabular}

Tabel 8. Table Rank Analisis Kualitas Aktiva Produktif (KAP) dan Penyisihan Aktiva Produktif (PPAP)

\begin{tabular}{lcc}
\hline \multicolumn{1}{c}{ BANK } & KAP & PPAP \\
\hline BCA & $\mathbf{1}$ & $\mathbf{1}$ \\
BRI & 2 & $\mathbf{2}$ \\
BNI & $\mathbf{3}$ & $\mathbf{3}$ \\
MAYA & 4 & $\mathbf{4}$ \\
PERMATA & $\mathbf{5}$ & $\mathbf{5}$ \\
\hline
\end{tabular}

Rasio Kualitas Aktiva Produktif (KAP) dari grafik bahwa BBRI, MAYA, BBCA dan BBNI dapat dikategorikan sehat karena rata-rata nilai nya berada dinilai range $0-10 \%$, nilai persentasi tiap tahunya selama 5 tahun pada bank BBRI,MAYA,BBCA dan BBNI terus menunjukkan angka yang meningkat hal ini disebabkan karena meningkatnya total aktiva produktif dari dana kredit yang diberikan masyarakat atau suatu instansi.
Dan BNLI dikategorikan tidak sehat karena memiliki nilai rata-rata rasio di atas $17,21 \%$ karena turunnya total aktiva produktif dari dana kredit yang diberikan masyarakat atau suatu instansi di tahun 2014 dan 2016.

Bank dikatakan sehat karena nilai Rasio PPAP nya berada diatas $81 \%$. Ini menunjukkan bahwa pada industri ini cukup menyediakan cadangan kerugian penurunan nilai dari total kredit yang diberikannya dari perbandingan penyisihan penghapusan aktiva produktif yang dibentuk (PPAPYD) terhadap penyisihan penghapusan aktiva produktif yang wajib dibentuk (PPAPWD). Sebaliknya, BNLI tidak cukup menyediakan cadangan kerugian penurunan nilai dari total kredit yang diberikan jadi tidak disarankan untuk berinvestasi bagi investor jangka panjang. 
Silmi et al, "Is The Banking Industry The Right Choice To Invest?"(Analisis Laporan Keuangan PT. Bank Central Asia, PT. Bank Rakyat Indonesia, PT. Bank Nasional Indonesia, PT. May Bank dan PT. Bank Permata Periode 2013-2017)

Tabel 9. Table Rank Analisis Earning

\begin{tabular}{|c|c|c|c|c|c|c|}
\hline ROA & BRI & MAYA & BBCA & BNLI & BBNI & AVERAGE \\
\hline 2013 & $4,45 \%$ & $1,50 \%$ & $3,59 \%$ & $1,39 \%$ & $1,9 \%$ & $2,57 \%$ \\
\hline 2014 & $3,84 \%$ & $0,60 \%$ & $3,75 \%$ & $1,10 \%$ & $1,8 \%$ & $2,22 \%$ \\
\hline 2015 & $3,69 \%$ & $0,90 \%$ & $3,81 \%$ & $-0,16 \%$ & $2,1 \%$ & $2,13 \%$ \\
\hline 2016 & $3,38 \%$ & $1,50 \%$ & $3,82 \%$ & $-5,22 \%$ & $2,7 \%$ & $1,24 \%$ \\
\hline 2017 & $3,28 \%$ & $1,20 \%$ & $3,89 \%$ & $0,64 \%$ & $2,0 \%$ & $2,20 \%$ \\
\hline AVERAGE & $3,73 \%$ & $1,14 \%$ & $3,77 \%$ & $0,39 \%$ & $2,10 \%$ & \\
\hline BOPO & BRI & MAYA & BBCA & BNLI & BBNI & AVERAGE \\
\hline 2013 & $43,10 \%$ & $154,00 \%$ & $49,36 \%$ & $65,91 \%$ & $\mathbf{5 0 , 9 \%}$ & $72,65 \%$ \\
\hline 2014 & $46,12 \%$ & $138,00 \%$ & $65 \%$ & $\mathbf{7 4 , 4 2 \%}$ & $60,8 \%$ & $76,95 \%$ \\
\hline 2015 & $47,62 \%$ & $151,00 \%$ & $62 \%$ & $96,48 \%$ & $53,1 \%$ & $81,97 \%$ \\
\hline 2016 & $48,88 \%$ & $152,00 \%$ & $60 \%$ & $205,91 \%$ & $70,7 \%$ & $107,44 \%$ \\
\hline 2017 & $48,65 \%$ & $152,00 \%$ & $58 \%$ & $88,91 \%$ & $66,0 \%$ & $82,65 \%$ \\
\hline AVERAGE & $46,87 \%$ & $149,40 \%$ & $58,76 \%$ & $106,33 \%$ & $60,30 \%$ & \\
\hline
\end{tabular}

Tabel 10. Table Rank Analisis ROA dan BOPO

\begin{tabular}{lcc}
\hline \multicolumn{1}{c}{ BANK } & ROA & BOPO \\
\hline BCA & 1 & 2 \\
BRI & 2 & 1 \\
BNI & 3 & 3 \\
MAYA & 4 & 5 \\
PERMATA & 5 & 4 \\
\hline
\end{tabular}

Untuk perusahaan bank yang paling mampu mengelola asetnya dengan baik dan mendapatkan laba terbesar dari assetnya adalah bank BBCA secara rata- rata menghasilkan nilai diatas 3\% dan cukup konsisten bertahan pada periode 5 tahun berjalan. Sedangkan untuk Bank yang terbaik nilai BOPO nya adalah Bank BRI ini menandakan bank BRI baik dalam pengelolaan biaya dalam menghasilkan pendapatan karena semakin kecil rasio berarti semakin efisien biaya operasional yang dikeluarkan bank, jadi dapat dikategorikan BRI sangat sehat. Ini menunjukkan pendapatan operasional bank selalu lebih besar dari pada biaya operasionalnya.

Tabel 11. Table Rank Analisis Likuiditas

\begin{tabular}{|c|c|c|c|c|c|c|}
\hline CR & BRI & MAYA & BBCA & BNLI & BBNI & AVERAGE \\
\hline 2013 & $29,11 \%$ & $23,00 \%$ & $17,50 \%$ & $31,00 \%$ & $13,5 \%$ & $22,8 \%$ \\
\hline 2014 & $36,61 \%$ & $25,00 \%$ & $16,55 \%$ & $13,00 \%$ & $14,4 \%$ & $21,1 \%$ \\
\hline 2015 & $40,63 \%$ & $30,00 \%$ & $25,25 \%$ & $0,19 \%$ & $15,9 \%$ & $22,4 \%$ \\
\hline 2016 & $39,75 \%$ & $20,00 \%$ & $19,81 \%$ & $18,00 \%$ & $15,8 \%$ & $22,7 \%$ \\
\hline 2017 & $39,01 \%$ & $22,00 \%$ & $15,13 \%$ & $18,00 \%$ & $20,5 \%$ & $22,9 \%$ \\
\hline AVERAGE & $37,02 \%$ & $24,00 \%$ & $18,85 \%$ & $16,04 \%$ & $16,02 \%$ & \\
\hline LDR & BRI & MAYA & BBCA & BNLI & BBNI & AVERAGE \\
\hline 2013 & $85,49 \%$ & $87,00 \%$ & $74,35 \%$ & $88,00 \%$ & $85,3 \%$ & $84,03 \%$ \\
\hline 2014 & $78,46 \%$ & $92,00 \%$ & $75,31 \%$ & $87,00 \%$ & $87,8 \%$ & $84,11 \%$ \\
\hline 2015 & $82,49 \%$ & $86,00 \%$ & $79,24 \%$ & $85,00 \%$ & $\mathbf{8 7 , 8 \%}$ & $84,11 \%$ \\
\hline 2016 & $85,63 \%$ & $88,00 \%$ & $76,01 \%$ & $71,00 \%$ & $90,4 \%$ & $82,21 \%$ \\
\hline 2017 & $84,86 \%$ & $86,00 \%$ & $77,23 \%$ & $79,00 \%$ & $85,6 \%$ & $82,54 \%$ \\
\hline AVERAGE & $83,39 \%$ & $87,80 \%$ & $76,43 \%$ & $82,00 \%$ & $\mathbf{8 7 , 3 8 \%}$ & \\
\hline
\end{tabular}

Tabel 10. Table Rank analisis CR dan LDR

\begin{tabular}{lcc}
\hline \multicolumn{1}{c}{ BANK } & CR & LDR \\
\hline BCA & 2 & 2 \\
BRI & 1 & 1 \\
BNI & 3 & 3 \\
MAYA & 4 & 5 \\
PERMATA & 5 & 4 \\
\hline
\end{tabular}

\section{SIMPULAN}

Bank yang dinilai baik untuk berinvestasi bagi investor jangka pendek dapat dilihat dari rasio price book to value dan debt ratio bank yang bersangkutan, sedangkan untuk investor jangka panjang dapat dilihat dari rasio EVA, financial Distress, DUPON, CAMEL dan Leverage. Sehingga dari hasil analisis dan penelitian, maka penulis memberikan rekomendasi kepada calon investor jangka pendek untuk berinvestasi di Bank BCA karena asset BCA masih lebih tinggi dibandingkan liabilitasnya, jadi liabilitas masih mampu ditutupi lewat asset yang dimilikinya dan nilai. Sedangkan untuk calon investor jangka panjang penulis merekomendasikan Bank BRI karena pada rasio EVA, Bank BRI dalam peringkat 1 dan NITAMI nya jauh jika dibandingkan dengan 4 bank lainnya, kemudian dari Financial Distress juga jauh dibawah batas Cut-Off meskipun rangking 2 akan tetapi tidak jauh berbeda dari bank BCA, sedangkan dari rasio CAMEL, BRI rata-rata juga menjadi rangking utama dibanding Bank lainnya. Sehingga Bank BRI merupakan industry sektor perbankan yang cocok dan direkomendasikan bagi investor jangka panjang. 


\section{DAFTAR PUSTAKA}

Aini, N. (2013). pengaruh CAR, NIM, LDR, NPL, BOPO, dan kualitas aktiva produktifterhadap perubahan laba (Studi Empiris Pada Perusahaan Perbankan yang terdaftar di BEI) Tahun 20092011. Dinamika Akuntansi Keuangan Dan Perbankan, 2(1).

Ariyanti, L. E. (2010). Analisis Pengaruh CAR, NIM, LDR, NPL, BOPO, ROA dan Kualitas Aktiva Produktif terhadap Perubahan Laba Pada Bank Umum di Indonesia. UNIVERSITAS DIPONEGORO,

Fitrianto, H., \& Mawardi, W. (2006). Analisis pengaruh kualitas aset, likuiditas, rentabilitas, dan efisiensi terhadap rasio kecukupan modal perbankan yang terdaftar di Bursa Efek Jakarta. Jurnal Studi Manajemen Organisasi, 3(1), 1-11.

Handayani, I. (2011). Analisis Laporan Keuangan Untuk Menilai Kinerja Keuangan Perusahaan Pada Perusahaan Industri Tekstil Yang Terdaftar Di Bursa Efek Indonesia.

Jiwandono, T. (2014). Analisis Faktor Fundamental Terhadap Harga Saham Sektor Perbankan yang Go Public di Indeks Kompas 100. Jurnal Ilmu Manajemen (JIM), 2(3).

Listyorini, W. W. (2012). Analisis pengaruh camel terhadap kinerja perusahaan perbankan yang go publik. Dinamika Akuntansi Keuangan Dan Perbankan, 1(2).

Rahmawati, A. I. E., \& Hadiprajitno, P. B. (2015). Analisis Rasio Keuangan Terhadap Kondisi Financial Distress pada Perusahaan Manufaktur yang Terdaftar di Bursa Efek Indonesia tahun 2008-2013. Fakultas Ekonomika dan Bisnis,

Sofyaningsih, S., \& Hardiningsih, P. (2011). Struktur kepemilikan, kebijakan dividen, kebijakan utang dan nilai perusahaan. Dinamika keuangan dan perbankan, 3(1), 68-87.

Subramanyam. (2017). Analisis Laporan Keuangan: Financial Statement Analysis. Penerbit Salemba Empat, Jakarta Selatan.

Sujarweni, W. (2015). Analisis Laporan Keuangan. Penerbit Erlangga. Jakarta.

Sutarti, R. P. D. (2011). Analisis Penggunaan PSAK 02 dalam Penyusunan Laporan Arus Kas untuk Mengukur Kinerja Keuangan pada Perusahaan. 